\title{
Black Theology of liberation: A theology of life in the context of Empire
}

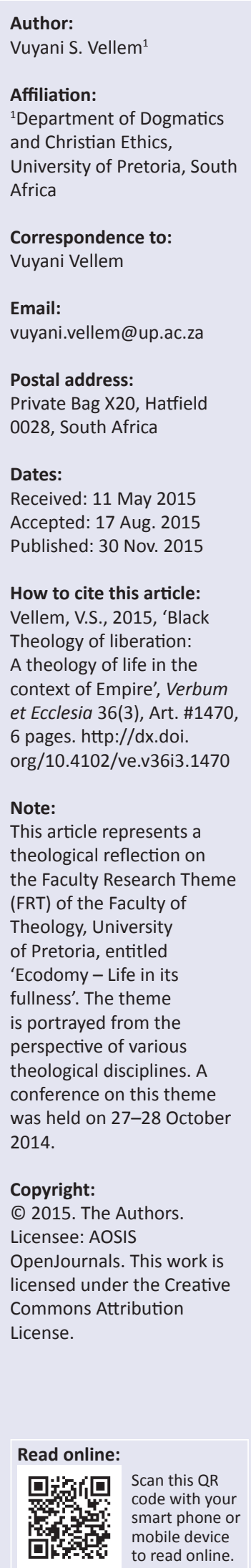

The cry for life by the peoples of the global South and all the victims of the vicious antics of Empire is our hope. Living against the logic of Empire is rebellion against the life killing order of Empire. This cry for life, the article argues, is our method for reasserting the goals of Black Theology of liberation as life - life as a precondition to all ethical claims. Racism cannot be treated as a marginal aspect of modernity and, ipso facto, economics. Capitalism exists in a symbiotic relationship between racism, hiding in the husk of Empire that feeds on the paradigms of life Empire destroys and kills. Using as an illustration the dynamics of the mind, unmasking the universe of Empire is the task of a Black Theology of liberation as a theology of life.

\section{Introduction}

This article builds on the argument that Black Theology of liberation is a discourse of life (see Vellem 2015a). The cry for life by theologians in the global South some 23 years ago, in a Statement with the title, A Cry for Life: The Spirituality of the Third World, is even louder than it was ostensibly loud to those who have obstinately refused to close their ears and turn their sight away from the voices of the black interlocutor in South Africa post-1994. Accordingly, 'the insistence of Black Theology of liberation on debunking the metaphysics of capitalism' (Vellem 2015a:177), calls upon us to return to the content of the cry of the marginalised and the continued onslaught on their spirituality and consciousness by Empire today.

Assuming that there is a deep relationship between race and economic exploitation, the article begins to engage the Statement, A Cry for Life: The Spirituality of the Third World, as the basis for locating itself within the experiences of suffering and the struggle history of the racially subjugated, as a theology of life. The article then moves on to clarify the mindset of Empire by employing the theory of mind dynamics so as to illustrate how the workings of a life killing Empire could be unmasked. To conclude the conversation, the article argues that a cry for life as rebellion against Empire is a theology of life. Unconcluding remarks are made at the end to suggest areas that could be pursued further to engage Empire.

\section{The cry for life}

About 23 years ago, in Kenya, the Ecumenical Association of Third World Theologians (EATWOT) produced a statement with the title, A Cry for Life: The Spirituality of the Third World (hereafter the Statement), which was published in the Journal of Black Theology in South Africa. This statement arose when there were changes that were taking place in the world, notably the demise of apartheid, the fall of the Berlin Wall and the collapse of the Soviet Union. There were signs of hope on the horizon but challenges too as the Statement suggests. Twenty one years later, after democracy in South Africa, this cry for life articulated 23 years ago, should be one of the most important texts to use to benchmark any progress that our democratic dispensation has made especially with regard to the conditions of the nonpersons or the black interlocutors of a Black Theology of liberation. These sentiments from the Statement (1993) are important:

The cry of the Third World is not a passive cry of resignation to the realities of death. It is a strident witness to the persistence of life. The cry for life is not a cry of despair, sorrow, hopelessness or grief. It is a cry that denies victory to torture, detainment, starvation and military might. It is a cry for bread, rice, water, land, housing, jobs health care. (p. 47)

True to the teachings of the liberation paradigm, the cry is a loud voice: 'raised from the midst of misery and from within situations in which the forces of death are rampant' (Statement 1993:47); surely 'a cry for life, life in all its fullness' (Statement 1993:47), later echoed in the Accra Confession in 2004. The issues that define this cry, or rather, the 
contents of this cry before the adoption of the Accra Confession, are almost the same as those stated in the Accra Confession. ${ }^{1}$ According to the Statement (1993:49), structures of oppression 'are global and local', and the problem of economics - the market economy - is pointed out as one whose 'catastrophic aspects on the poor and the marginalized' (Statement 1993:47), would continue to worsen rather than become better.

Importantly, the Statement (1993:50) then says that there are currents that inspire a 'vision for a new way of living'. These currents include, amongst others, the struggles of women, the movements of black peoples, the indigenous movements and religions, as well as Hispanic and ecological movements. Alluding to our context in South Africa, the Statement (1993) said:

In South Africa, the anti-apartheid struggle gave birth to the Black Consciousness movement. Blacks in South Africa have set foot on the path of being autonomous subjects of their history. The current movement of liberal democracy in Africa is not seen as life-saving. The poor will be even more powerless. They will be alienated from their land and get deeper and deeper into the culture of violence. (p. 52)

The resistance of the young people and their anger, women and their struggles against patriarchy, including all these currents that inspire a new vision of living, express hope that denies death and affirms life. The development of distinctive theologies by women in addition to class and race constructs that deny black peoples their dignity and life, is an expression of the power of the oppressed to say 'no' to death.

Empire is life denying. According to the Statement, these currents above shape the theology of the Third World and, in our case, a Black Theology of liberation as a theology of life. The spirituality of these global currents and movements that resist death is our methodological thrust for a theology that affirms life as the Statement (1993:57) itself asserts: 'We have been insisting that our method is our spirituality'. The spirituality for life in a Black Theology of liberation is, amongst others, the energy to holding on to life in conditions of death. All of life is regarded as spiritual without any dichotomies; hence, a cry for life and that power to resist death, providing strength to live, puts our understanding of God as embedded in the struggles of the marginalised. Jesus becomes the rootage of this spirituality, Jesus who faces the same struggles in life that the nonpersons face. The biblical hermeneutics of a Black Theology of liberation moves from within the context of the cry for life by the poor. The proposal for a search of alternatives by the Statement suggests a move beyond capitalism to socialism and building alliances with people and learning from them. ${ }^{2}$

\footnotetext{
1.See the introduction of A Cry for Life: The Spirituality of the Third World (1993:2647) and the section on 'Reading the Signs of the Times' of the Accra Confession (1993:170-171). Our reading of these two documents sees similarities of content (1993:170-171). Our reading
barring their different tones.

2.The section that reflects theologically on this context of death by the Statement (1993:57-71) is not repeated but summarised for our purpose.
}

\section{Racism and the capitalist neoliberal economics}

Black Theology of liberation is a reflection of faith praxis from within the underside of modernity and thus a response to modernity, namely the theories of modernity and its assumptions. This school argues that there is a link between racism and neoliberal economics. Broadly speaking, Black Theology of liberation holds that modernity totally and violently excludes the black African perspective in the creation of knowledge, that is, the black African cultural dispensation, or world-creating value system and further dehumanises living labour and the lived experience of the oppressed black African people. For this reason, Black Theology agrees with the view that the anthropology of modernity is heretical (Saayman 2007:135).

This argument resonates with Dussel's view that ethically, 'the critical problem of our time - the one that affects far more people far more adversely - is global neo-colonialism' (Alcoff \& Mendieta 2000:7). In this regard, the underside of modernity is an adverse catastrophic experience of total and violent exclusion of black Africans that mirrors the root connection between economics, racism and the current neocolonial models of economic management.

Assuming that politics and ethics are two sides of the same coin, at the core of our argument therefore is the view that colonialism and imperialism are not marginal concepts of modernity, but central topics within the history of political and social thought in the West, ipso facto, colonialism and imperialism must be central to Western, or European theological and ethical thought.

Moving from this assumption, the problem is that much as there is a tendency to overlook colonialism and imperialism as integral to the designs and ponderings of Western political theories, Western theological discourse similarly appears to treat colonialism and imperialism largely as peripheral matters to its ponderings. ${ }^{3}$ According to Sugirtharajah (2004:22), 'more books have been written by Western theologians about being nice to animals and the environment than about colonialism or race'. It is not this apparent obviation of the centrality of colonialism, imperialism and race that matters more for me than the justification of colonialism and imperialism even by such eminent icons of theological thought in the West such as Reinhold Niebuhr. Sugirtharajah (2004:23-27) offers an analysis of the theological justification of Empire by Max Warren and Reinhold Niebuhr, and says this about them:

The writings of Niebuhr and Warren emphasize lofty intensions of uplifting depraved but appreciative natives. There is a passionate belief in empire, but how the enterprise is essential to the well-being of the Western powers hardly comes into the equation. While pointing out the benefits bestowed on the colonies, no reference is made to colonies as sources of raw

3.This is a persistent problem in South Africa perhaps best expressed in the a.r......... that South Africans should move heyond rachaps best expressed in the argument this question might help this question might help expand on this debate even though the same work simply dismisses the futility of the view dubbed as postracialism in South Africa and in the U.S.A. (see eds. Ackah, Reddie \& Tshaka 2015) 
material, cheap labour, secure markets, and potential sites of investment. (Sugirtharajah 2004:26)

Whilst there seems to be very little interest in analysing colonialism and imperialism as central pivots of modernity, there is more it seems in that omission - the omission of racism as part of modernity. It is eloquently an ostensible justification of Empire as beneficial to those who live on its underside. But one has to remember that:

Not so long ago Western societies claimed the name 'modernity' for their time, their contemporaneity, assuming this to be at the forefront of the historical continuum. Modernity was a selfdescription that served as a self-affirmation, differentiating the West from the rest. Today, modernity has given way to globalization, or the global age, as a way to describe societies, though not merely or necessarily those of the industrialized West. Already there is a highly developed bibliography of materials seeking to explain how globalization came to pass and what its implications are for different types of society. (Alcoff \& Mendieta 2000:1)

The contemporaneity of racism (with capitalism, colonialism, imperialism and Empire) constitutes a continuum giving way to globalisation, but more deeply so, a continuum between modernist theories of politics, theology and ethics right into the ponderings of the current world order. According to Levy and Young (eds. 2001:xi), 'Modernity - the centuries since 1500 - has been at once the era of the European state and the era of the European empires'. Levy and Young (eds. 2001:xi) continue to say, 'European colonialism and imperialism ultimately reached a global scale that dwarfed what had come before'. One cannot describe those who fail to recognise racism for what it is, especially apartheid in the historical failures of modernity in the 20th century. The interpretation of South African public life post-1994 that delinks apartheid from colonialism and colonialism from modernity is exemplified by some views that point to the beneficial aspects of apartheid and colonialism without engaging the fundamental pillars of apartheid and its link to modernity. Before we move on to the next point of our conversation, these words by Enrique Dussel (2011) require our attention:

What the liberation of diverse types of oppressed and/or excluded populations presupposes is the overcoming of cynicalmanagerial reason (planetary administrative) of capitalism (as an economic system), of liberalism (as a political system), of Eurocentrism (as an ideology), of machismo (in erotics) of the reign of the white race (in racism), of the destruction of nature (in ecology), and so on. (p. 111)

Black Theology of liberation situates race analysis in modernity and envisions knowledge forms that seek to overcome the 'reason' of capitalism, liberalism, macho power, Eurocentrism, racism and ecocide, politically and theologically, to mention but a few. In this light, we situate the ponderings of racism and neoliberal economics within Western modernity, ipso facto, the ponderings of apartheid and its residues in post-1994 South Africa. Stated otherwise, the anatomy of whiteness is racism. Eze (2011) clarifies this matter as follows:

Colonialism as a mode of imperial expansion was part of a larger historical process - it contributed to Europe's self-fashioning into a force of global capitalist modernity. The brutality of this modern economic process is nowhere evident as in the institution of transatlantic slavery. The antiquities in all societies from the Athenian through the Ashanti to the Roman - seem to have known slavery in some form: indentured servitude, religious caste systems, or other forms of extreme class division within a society that renders a particular section of population exploitable, with or without rights of citizenship. But scholars of slavery agree that there was something unique and unrepeatable about modern, transatlantic, and racial African slavery. For the first time in human history the enslaver did not call the enslaved 'dog' or 'beast' merely metaphorically. On account of skin color, it was presumed that Africans were as 'race unlike any other' a race whose enslavement, regardless of class or caste, was considered 'scientifically' valid. (p. 224)

In the Statement, theologians of the global South (EATWOT) 23 years ago specifically present the beginning of the socalled New World Order (1492) as a specific challenge to which we must respond. The Statement (1993:64) says that the global South was now 'destined to become absorbed into this new European world order'; since then, a different model of anthropology began to exist, bifurcated between White Christian Europe and all other peoples of the global South with whiteness as a norm. The Statement (1993) says:

Through the process of modernization, Europe and later North America were so convinced of their own superiority that they would develop historical, philosophical and theological teachings about the fundamental inequality of the races. This would further the moral legitimation to colonialism with all its mechanisms of exploitation of the colonies and their peoples. (p. 65)

The tendency to treat racism as a marginal concept to capitalism in the same way as colonialism has been treated as a marginal concept to modernity is the thrust of our conversation in this article. The absence of the word racism in theology or the treatment of racism as marginal to theological discourse is equally as cynical. In South Africa's case, many white South Africans, for example, will easily acknowledge that apartheid was wrong. Saayman (2007:135) observed that 'DRC members do not have a clear understanding at all of the essential racist essence of apartheid and what apartheid actually did to all South Africans'. Often, and here we follow Saayman's explanation, the acknowledgement of the wrongs of apartheid is confined to the external symptoms of apartheid such as its laws and physical atrocities many blacks suffered, and not the root cause itself which in our view is apartheid's symbiosis with modernity and consequently its distorted anthropology. At the heart of Cone's (1980) theological response to this deficient understanding of racism is the following:

The uniqueness of black oppression is not to be understood theologically as if blacks are elected by God but only scientifically. It is a fact that most people who suffer in the world are people of color and not European. And it is a fact that the people responsible for that oppression are white Europeans. Marxists have to be open to hear the meaning of that fact by asking whether fascism is inherent in the very nature and structure of western civilization. (p. 28) 
It is the scientific fascism of modernity that underlies the propensity to confine the damage of racism within the external dimension of the damage it caused to black people rather than the essential core of racism as an integral part of modernity in the same way as capitalism is. Pigmentocracy is the creation of modernity; it is a science of modernity, its philosophy, its history, economics and theology to say the least. How does this logic continue to find expression in the 21st century? This is the question we briefly turn to now. Allan Boesak's (2015:2-3) explanation of the fundamentals of oppression and the system of apartheid in South Africa provides a good list of aspects that matter for Black Theology's response to modernity.

\section{Unmasking the husk of Empire}

One of the problems of Empire is its opacity (Vellem 2015a:181-184). Modernity as an adverse catastrophic experience lived by black people up to this day calls upon a repudiation of the treatment of colonialism as marginal particularly in discourses that suggest a 'post' to colonialism without mitigating the tragic relationship between modernity and colonialism. ${ }^{4}$ Most of the debates in South Africa post-1994 are faulted along these lines; they continue with philosophical, economic, political and theological insights based on the scientific fascism of modernity. Despite the warning contained in the Statement by EATWOT theologians more than two decades ago, the conspicuous inability in our public mindset to relate liberal democracy to the philosophies of modernity and consequently its inability to become 'a democracy that also provides bread' for those historically excluded in the knowledge forms and systems of modernity, remains a vexing question for us. Jesse Mugambi (2003) asks this important question about democracy:

Why did the powers now calling for 'democratization' in Africa discourage 'temporary' (or acquiesce at its erosion) during the past thirty years? Why has 'democratization' become important after the collapse of the Soviet Union? The lack of convincing answers to these questions makes many people to wonder about the real motives of affluent nations for sponsoring 'democratization in Africa. (p. 100)

For us this lack of convincing answers suggests that Empire is hidden in liberal democracy or more generally and broadly speaking in the fascist creation of knowledge associated with modernity. Whilstit is clear to everyone that political liberation could never have been sufficient for the comprehensive liberation of those living on the underside of modernity, the horrifying spectre of the fetishes of neoliberalism continues to consume and destroy in all spheres of life. Still, in the context of such horrifying conditions post-1994 in South Africa, blind obedience to modernity continues to shape our policies in economics for example. Perhaps a glance on the relationship between the fetishes of modernity and spirituality could lead to an understanding of this problem, namely, blind loyalty to modernist forms of knowledge, the spectre of horrifying episodes of blind loyalty to political leader with answers

4.For a longer discussion of postcolonial discourse and its relationship with the liberation paradigm, see Vellem (2015b). all the time that are not convincing. The husk of Empire is hidden in spirituality today, we argue.

To explain this point, Mike Muendane's (2006) thesis on mindset could help us. Muendane (2006:19) argues that in order to eliminate the colonial mentality, mind dynamics could be a helpful approach. He says that examining mindsets and their relationship with behaviour and outcomes is invaluable to overcome the colonial mindset. One does not need to repeat Muendane's thesis here, but the insightful exposition on how meaning is constructed. According to Muendane (2006):

When a single or combination of references are linked to the object (situation at hand), the result is what the situation means for the individual. The mind needs to construct that meaning before it can act on the situation; it has to attach value to it. (p. 17)

More importantly is that in the operation of the mind, levels of certainty range from low to high. This means that these concepts: notion, idea, perception, opinion, assumption, belief, model, pattern of thought, conviction and faith, occupying different levels in the operation of the mind, ultimately determine meaning or paradigm as he actually explains (Muendane 2006:17).

Empire evokes the manipulation of paradigm or meaning in life. Empire occupies these levels of certainty of meaning. Empire colonises these levels of certainty of meaning to create notions, ideas, perceptions, opinions, assumptions, beliefs and ultimately faith, for its own sake. This is what we have called the fetish of Empire (Vellem 2015a:182). This is what the spirituality of Empire does; its husk is hidden in the notions, ideas and ultimately the dominant faith paradigms we see in our country today and the world. Often, the notions of life, the perceptions of life, the opinions and models of life, are propagated as life-affirming, whilst the core paradigm of Empire is itself a threat to the whole constellation of life. Stated otherwise, the notions of the people, their common spontaneous knowledge, their perceptions, their opinions, their models, are now strictly speaking engrafted on the hidden core of Empire, the core metaphysical paradigm of capitalism which has no interest in the lives of the poor. Meaning as a whole is absorbed by Empire and thus the requisite task to unmask its antics. Once consumed in the mindset of Empire, the lives of the poor literally become miserable. The Statement (1993) says:

The cry of the Third World is from the midst of the politics of the powerful who rule by torture, assassination and the contriving of the disappearance of women and men, and who commit aggression through proxy wars. The cry raised from the midst of structures designed for our subjugation, marginalization and extinction, through distorted priorities, skewed agricultural policies, unjust trade arrangements and inhumane economic manipulations and pressure tactics - all practised and imposed in brutal and subtle ways by neo-colonialism and international imperialism of money built up through the atrocities, cruelties and robberies during the era of military colonialism. (p. 47)

Of course the sentiments were made two decades ago, but it is not difficult to agree with the thrust that runs through 
these lines. In South Africa we have now become familiar with violence in politics, we have seen proxy wars in post1994 South Africa and the Marikana massacre is but one of the worst examples of this violence. The structures that are designed to subjugate and annihilate are everywhere in the open and the recent 'Rhodes must Fall' campaign at the University of Cape Town is one example of the struggle against these structures. All these distortions are paradigmatic cruelties and robberies of modernity and its colonising, conquering and christianising mindset. The fall of the Berlin Wall and the demise of apartheid cannot and will not necessarily imply the change of mindset. These walls and their values and goals are in the mindset. To perpetuate these goals and values, Empire colonises the mindset.

Unmasking the husk of Empire is decolonising the mindset. It is about liberating the notions, ideas, perceptions, opinions, assumptions, beliefs, models, patterns of thought, convictions and faith from the husk of Empire. Unmasking the husk of Empire means transformation into a new universe ${ }^{5}$ of meaning, a new universe of meaning that is life-affirming. A return to some of the aspects that Karl Marx raised as in the title of the book by Terry Eagleton, Why Marx Was Right (2011), is equally helpful to unmask the notions that are related to capitalism in the quest for a life-affirming theology.

\section{The cry for life is a theology of life}

Generally speaking, the view that Black Theology is a theology of life derives from a particular understanding of the word or concept 'life'. Life is understood as the starting point of ethics, a precondition of all ethical claims or systems (cf. Petrella 2008:13ff.). God is thus understood as God of life and this understanding of life is not an abstract but material, bodily life; for example, Gustavo Gutiérrez (2007:11) says 'resurrection is the victory of life over death, while poverty means simply death'. We need to turn this around. There is a sense in which resurrection is rebellion and in the struggles for life, the nonperson rebels against the life killing sprit of Empire. Rebellion against death is to live in the context of Empire without the ideals and notions of Empire. Rebellion against death is to deny victory to torture and starvation in the context of the militarisation of life by Empire. Rebellion against death is bodily resurrection. The symbiosis between neoliberal capitalism and racism is at its core life killing, but both the philosophy of liberation (Dussel 2008) and its theology posit life itself as a 'sovereign' starting point and a precondition of any claims and systems in the world. The Accra Confession sees Empire as death dealing and life killing exactly because of this ethical analysis on life that has developed in years within the paradigm of liberation. The cry for life by nonpersons on which Black Theology of liberation has constantly reflected is therefore a cry for God to be the God of life.

As indicated earlier, the Statement clearly suggests that this cry for life is not a passive resignation to the life killing 5.See how Saayman (2007:134-135) uses the notion of a new universe in his
discussion of the theological discourses that continue to trouble union in the Dutch Reformed Churches in South Africa. antics of Empire. The Statement (1993:57) further says that celebration of life is a spiritual response to the cry for life and thus, the spiritual traditions of the indigenous peoples - Native Americans, Aborigines, Maori's, Dalits, Tribal peoples of India and Black Africans in Africa - are a powerful reminder of this fact' including the struggles for life by women. The Statement (1993) goes on to say:

There is a life force that urges them to seek the glory of God and of creation by seeking the glory of the whole of humanity, for so to do is to seek a humanity fully alive. (p. 58)

One may say this is a bit too theoretical. By no means! In unmasking the universe of Empire and its mindset, there is no theory but the praxis of the peoples of the South and all those totally excluded and oppressed, living on the underside of modernity with its effects of racism and capitalism. The cry for life as rebellion and thus insurrection against life killing systems is 'the capacity of the oppressed to change the conditions of their being and in the process change themselves' (Wa Thiongo n.d.:27 of 27).

As a theology of life, the cry for life by those living in conditions that are life killing, as we have already said not a passive cry - provides the active artefacts of critical consciousness and transformation as the nonperson becomes an agent of his or her life. Ngungi Wa Thiongo (n.d.:10) makes this point poignantly: 'one is transformed by that act of trying to transform'.

\section{Unconcluding thoughts}

Black Theology of liberation has to contend with the argument that European modernity is racist at its core. In post-1994 South Africa and certainly in global discourses on the challenges associated with Empire, to treat racism as a marginal aspect to capitalism might imply turning a blind eye to the fascist nature of knowledge associated with modernity. Perhaps those who have the liberty and the space to do so could continue, but the cry for life is simply unbearable to those who can hear it. The more we break the seals of Empire, the more we peel the husk of Empire, the louder the cry. In these adverse catastrophic experiences of black Africans, women and creation, the energy to hold on to life is our method of spirituality for life. Unmasking the husk of Empire is a spiritual matter for decolonisation.

\section{Acknowledgements Competing interests}

The author declares that he has no financial or personal relationships which may have inappropriately influenced him in writing this article.

\section{References}

Ackah, W., Reddie, A. \& Tshaka, R. (eds.), 2015, Contesting post-racialism: Conflicted churches in the United States and South Africa, University of Mississippi Press, MS.

Alcoff, L.M. \& Mendieta, E., 2000, 'Introduction', in L.M. Alcoff \& E. Mendieta (eds.), Thinking from the underside of history: Enrique Dussel's philosophy of liberation, pp. 1-7, Rowman \& Littlefield Publishers, Oxford. 
Boesak, A., 2015, Kairos, crisis and global Apartheid, Palgrave Macmillan, New York. Cone, J.H., 1980, The black church and Marxism: What do they have to say to each other?, Union Theological Seminary, New York.

Dussel, E., 2008, Twenty theses on politics, Duke University Press, New York.

Dussel, E., 2011, "The "world-system": Europe as "center" and its "periphery" beyond Eurocentrism', in J.T. Levy \& M.I. Young (eds.), Colonialism and its legacies, pp. 97-120, Lexington Books, MD.

Eagleton, T., 2011, Why Marx was right, Yale University Press, New Haven.

Eze, E.C., 2011, 'Double consciousness and the democratic ideal', in J.T. Levy \& M.I. Young (eds.), Colonialism and its legacies, pp. 219-242, Lexington Books, MD.

Gutiérrez, G., 2007, 'Liberation theology for the twenty-first century', in P.H. Closkey \& J.P. Hogan (eds.), Romero's legacy: The call to peace and justice, pp. 1-30, Rowman \& Littlefield Publishers, MD.

Sugirtharajah, R.S., 2004, 'Complacencies and cul-de-sacs', in M.N. Keller \& M. Rivera, Postcolonial theologies: Divinity and empire, pp. 22-38, Chalice Press, St. Louis.

Levy, J.T. \& Young, M.I. (eds.), 2001, Colonialism and its legacies, Lexington Books, MD.

Muendane, N., 2006, I am an African: Embrace your identity, escape victimization, Soul Talk, Buccleuch.
Mugambi, J.N.K., 2003, Christian theology and social reconstruction, Acton, Nairobi.

Petrella, I., 2008, Beyond liberation theology: A polemic, SCM, London.

Saayman, 2007, Being missionary, being human: An overview of Dutch Reformed Mission, Cluster Publications, Pietermaritzburg.

Sugirtharajah, R.S., 2004, 'Complacencies and cul-de-sacs', in M.N. Keller \& M. Rivera (eds.), Postcolonial theologies: Divinity and empire, pp. 22-38, Chalice Press, St. Louis.s

The Cry for Life - The Spirituality of the Third World (Statement), 1993, Journal of Black Theology in South Africa 1, 45-71.

Vellem, V., 2013, 'A critical black analysis of the Church's role in post-Apartheid struggle for socio-economic justice', Studia Historiae Ecclesiaticae XXXIX(2), 113-130.

Vellem, V.S., 2015a, 'Black Theology of liberation and the economy of life: Black Theology and economy of life', The Ecumenical Review 67(2), 177-186. http:// dx.doi.org/10.1111/erev.12149'

Vellem, 2015b, 'Unshackling the Church', forthcoming in HTS.

Wa Thiongo, N., n.d., In the name of the mother: Reflections on writers and empire, James Curry, Nairobi. 